\title{
Nematodes of zoonotic importance in Cynoscion guatucupa (Pisces) in the state of Rio de Janeiro
}

\author{
Nematóides de importância zoonótica em Cynoscion guatucupa (Pisces) no estado do Rio de Janeiro \\ Gabrielle Fontenelle ${ }^{1}$; Marcelo Knoff ${ }^{2 *}$; Nilza Nunes Felizardo²; \\ Leila Maria Silva Lopes ${ }^{1}$; Sérgio Carmona de São Clemente ${ }^{1}$
}

\author{
${ }^{1}$ Laboratório de Inspeção e Tecnologia de Pescado, Faculdade de Medicina Veterinária, \\ Universidade Federal Fluminense - UFF, Niterói, RJ, Brasil \\ ${ }^{2}$ Laboratório de Helmintos Parasitos de Vertebrados, Instituto Oswaldo Cruz, \\ Fundaçáo Oswaldo Cruz - FIOCRUZ, Rio de Janeiro, RJ, Brasil
}

Received December 17, 2012

Accepted February 27, 2013

\begin{abstract}
Between January and August 2012, thirty specimens of Cynoscion guatucupa (Cuvier, 1830) caught off coast of the municipality of Itajaí, state of Santa Catarina, Brazil (26 54' $28^{\prime \prime} \mathrm{S}$ and $\left.48^{\circ} 39^{\prime} 43^{\prime \prime} \mathrm{W}\right)$ and commercialized in the state of Rio de Janeiro were investigated for the presence of zoonotic nematodes. In total 853 larvae of four nematode parasite species were found. There were three species of Anisakidae: three larvae of Anisakis sp., with prevalence (P) of $10 \%$, mean intensity (MI) of 1.0 , mean abundance (MA) of 0.1 and infection site (IS) in the mesentery; five of Terranova sp. with $\mathrm{P}=13.3 \%, \mathrm{MI}=1.25, \mathrm{MA}=0.17$, range of infection (RI) from 1 to 2 and $\mathrm{IS}=$ mesentery; and seven of Contracaecum sp. with $\mathrm{P}=6.6 \%, \mathrm{MI}=3.5, \mathrm{MA}=0.23, \mathrm{RI}=1$ to 4 and $\mathrm{IS}=$ mesentery and abdominal cavity. There was one species of Raphidascarididae: 838 larvae of Hysterothylacium deardorffoverstreetorum with $\mathrm{P}=83.3 \%$, $\mathrm{MI}=33.52, \mathrm{MA}=27.93, \mathrm{RI}=1$ to 219 and $\mathrm{IS}=$ mesentery, liver serosa and abdominal cavity. This is the first report of larvae of Anisakis sp. and Contracaecum sp in C. guatucupa in Brazil.
\end{abstract}

Keywords: Hysterothylacium deardorffoverstreetorum, Anisakis sp., Terranova sp., Contracaecum sp., Cynoscion guatucupa.

\section{Resumo}

Entre janeiro e agosto de 2012, 30 espécimes de Cynoscion guatucupa (Cuvier, 1830) pescados no litoral do município de Itajaí, estado de Santa Catarina, Brasil (26 $54^{\prime} 28^{\prime \prime} \mathrm{S}$ and $48^{\circ} 39^{\prime} 43^{\prime \prime} \mathrm{W}$ ) e comercializados no estado do Rio de Janeiro, foram investigados quanto à presença de nematóides zoonóticos. Foram encontradas 853 larvas de quatro espécies de nematóides parasitos. Três espécies pertencem à Anisakidae, sendo três larvas de Anisakis sp., com prevalência $(\mathrm{P})$ de $10 \%$, intensidade média (IM) de 1, abundância média (AM) de 0,1 e sítio de infecção (SI) o mesentério; cinco de Terranova sp., com $\mathrm{P}=13,3 \%, \mathrm{IM}=1,25, \mathrm{AM}=0,17$, amplitude de variação da intensidade de infecção (AI) de 1 a 2 e SI = mesentério; e sete de Contracaecum sp., com $\mathrm{P}=6,6 \%, \mathrm{IM}=3,5, \mathrm{AM}=0,23, \mathrm{AI}=1$ a 4 e $\mathrm{SI}=$ mesentério e cavidade abdominal. Uma espécie pertence à Raphidascarididae, sendo 838 larvas de Hysterothylacium deardorffoverstreetorum com $\mathrm{P}=83,3 \%, \mathrm{IM}=33,52, \mathrm{AM}=27,93, \mathrm{AI}=1$ a 219 e $\mathrm{SI}=$ mesentério, serosa do fígado e cavidade abdominal. Este é o primeiro registro de larvas de Anisakis sp. e Contracaecum sp. em C. guatucupa no Brasil.

Palavras-chave: Hysterothylacium deardorffoverstreetorum, Anisakis sp., Terranova sp., Contracaecum sp., Cynoscion guatucupa.

\section{Introduction}

Cynoscion guatucupa (Cuvier, 1830), the striped weakfish, belongs to the family Sciaenidae, has a distribution range from the southwestern Atlantic coast of Rio de Janeiro, Brazil, to the

\footnotetext{
*Corresponding author: Marcelo Knoff

Laboratório de Helmintos Parasitos de Vertebrados, Instituto Oswaldo Cruz,

Fundação Oswaldo Cruz - FIOCRUZ, Av. Brasil, 4365, Manguinhos,

CEP 21045-900, Rio de Janeiro, RJ, Brazil

e-mail: knoffm@ioc.fiocruz.br
}

Gulf of San Matias, Argentina, and has great commercial value. It is a demersal species, found at depths of up to 200 meters and it also occurs in brackish waters of estuaries. Juveniles feed mainly on crustaceans and adults feed basically on fish (MENEZES; FIGUEIREDO, 1980; BERNARDES et al., 2005; FISCHER et al., 2011).

In Brazil, there are several records of parasitism in marine fish by Anisakidae and Raphidascarididae, and some of these nematodes 
have zoonotic potential. With the growth in consumption of raw fish (mainly related to Japanese cuisine), the risk of occurrences of zoonoses caused by these nematodes has increased, thus making this a public health problem. Recently, a case of anisakidosis was reported in Brazil (CRUZ et al., 2010).

Anisakidosis results from the combination of two factors: direct action by the larvae of Anisakidae during tissue invasion; and interactions between the host immune system and the substances released by the parasite or through its presence (UBEIRA et al., 2000).

The present study aimed to investigate nematode larvae of zoonotic importance infecting C. guatucupa commercialized in the municipality of Rio de Janeiro, state of Rio de Janeiro, Brazil, and thus to establish the helminth species and their parasitological indexes relating to prevalence, mean intensity, mean abundance, range of infection and infection sites, along with their sanitary importance.

\section{Materials and Methods}

Between January and August 2012, thirty specimens of Cynoscion guatucupa (Cuvier, 1830), the striped weakfish, of total length (tl) $38-45 \mathrm{~cm}$ and weight $0.550-0.735 \mathrm{~kg}$, were investigated for the presence of anisakid nematodes. These specimens were caught off coastal of the municipality of Itajaí, state of Santa Catarina, Brazil (26 54' $28^{\prime \prime} \mathrm{S}$ and $\left.48^{\circ} 39^{\prime} 43^{\prime \prime} \mathrm{W}\right)$ and were purchased in the wholesale food supply market of Rio de Janeiro (Central de Abastecimento de Alimentos of Rio de Janeiro, CEASA-RJ). The fish were conserved in an insulated box with ice and were then transferred to the Fishery Technology and Inspection Laboratory of the Veterinary School, Fluminense Federal University, Niterói, RJ. The specimens were identified in accordance with Menezes and Figueiredo (1980) and were then necropsied and filleted.

Nematode larvae were recovered in Petri dishes in a $0.65 \%$ $\mathrm{NaCl}$ solution, and were fixed with hot $\left(60^{\circ} \mathrm{C}\right) \mathrm{AFA}$, preserved in $70^{\circ} \mathrm{GL}$ ethanol and clarified with Aman's lactophenol as described by Eiras et al. (2006). The taxonomic classification used for the Anisakidae and Raphidascarididae followed the system of Fagerholm (1991) and larval identification was obtained in accordance with Petter and Maillard (1988), Timi et al. (2001), Felizardo et al. (2009) and Knoff et al. (2012). The larvae were observed by means of an Olympus BX-41 brightfield microscope and measurements were made in millimeters $(\mathrm{mm})$ with means in parentheses. Parasitological indexes relating to prevalence, mean intensity, range of infection and mean abundance were used as described by Bush et al. (1997). Representative specimens of the Anisakis sp., Contracaecum sp., Terranova sp. and Hysterothylacium deardorffoverstreetorum were deposited in the Helminthological Collection of the Oswaldo Cruz Institute (CHIOC).

\section{Results}

Among the 30 specimens of C. guatucupa collected, 83.3\% $(n=25)$ were parasitized by third-stage larvae of at least one species of the nematode families Anisakidae and Raphidascarididae, with a total of 853 parasites specimens. Three larvae of Anisakis sp., five of Terranova sp. and seven of Contracaecum sp. were collected. However, the species Hysterothylacium deardorffoverstreetorum predominated in all the positive fish, with 838 specimens. This is the first report of parasitism in C. guatucupa by Anisakis sp. and Contracaecum sp. larvae in Brazil.

The parasitological indexes relating to prevalence, mean intensity, range of infection and mean abundance, as well as the infection sites and the CHIOC deposit numbers are depicted in Table 1.

Morphological and morphometric data on the third-stage larvae of Anisakis sp., Contracaecum sp., Terranova sp. and $H$. deardorffoverstreetorum were obtained from three, four, three and ten specimens of C. guatucupa, respectively, and are presented in Table 2.

\section{Anisakidae Railliet \& Henry, 1912 \\ Anisakis Dujardin, 1845 \\ Anisakis sp.}

Main features observed in the third-stage larvae: anterior extremity with one dorsal and two poorly developed ventro-lateral lips. Six cephalic papillae, one pair in the dorsal lip and one pair in each ventro-lateral lip. Boring tooth below the oral aperture, between the two ventro-lateral lips. Excretory pore opening beneath the boring tooth. Ventriculus length greater than width. Ventricular appendix and intestinal cecum absent. Two nearly spherical rectal glands. Tail conical and mucron present.

\section{Contracaecum Railliet \& Henry, 1912 \\ Contracaecum sp.}

Main features observed in the third-stage larvae: cuticle with thin transversal striation, more evident in the posterior extremity of the body. Anterior extremity with one dorsal lip and two poorly developed ventro-lateral lips. Six cephalic papillae, one pair in the dorsal lip and one pair in each ventro-lateral lip. Boring tooth near the oral aperture, between the ventro-lateral lips. Excretory

Table 1. Prevalence (P), mean intensity (MI), mean abundance (MA), range of infection (RI), infection site (IS) and CHIOC deposit number of third-stage larvae collected from Cynoscion guatucupa (Cuvier, 1830) commercialized in the state of Rio de Janeiro, Brazil, between January and August 2012.

\begin{tabular}{|c|c|c|c|c|c|c|}
\hline & $\mathbf{P}(\%)$ & MI & MA & RI & IS & CHIOC \\
\hline Anisakis sp. & 10 & 1 & 0.1 & - & $\mathrm{M}$ & 35853,35854 \\
\hline Contracaecum sp. & 6.6 & 3.5 & 0.23 & $1-4$ & $\mathrm{M}, \mathrm{AC}$ & 35855 \\
\hline Terranova sp. & 13.3 & 1.25 & 0.17 & $1-2$ & M & 35856 \\
\hline Hysterothylacium deardorffoverstreetorum & 83.3 & 33.52 & 27.93 & $1-219$ & M, LS, AC & 35857,35858 \\
\hline
\end{tabular}

$\mathrm{M}=$ mesentery; $\mathrm{LS}=$ liver serosa; $\mathrm{AC}=$ abdominal cavity. 
Table 2. Morphological and morphometric data on Anisakidae and Raphidascarididae third-stage larvae collected from Cynoscion guatucupa (Cuvier, 1830) commercialized in the state of Rio de Janeiro, Brazil, between January and August 2012.

\begin{tabular}{ccccc}
\hline & Anisakis sp. & Contracaecum sp. & Terranova sp. & $\begin{array}{c}\text { Hysterothylacium } \\
\text { deardorffoverstreetorum }\end{array}$ \\
\hline Length & $22.25-23.50(22.33)$ & $2.9-4.25(3.37)$ & $4.5-6.75(4.92)$ & $9.35-13.75(11.16)$ \\
Width & $0.42-0.45(0.44)$ & $0.11-0.15(0.13)$ & $0.12-0.21(0.16)$ & $0.31-0.40(0.36)$ \\
Larval tooth & present & present & present & absent \\
Excretory pore* & opens beneath boring tooth & opens beneath boring tooth & opens beneath boring tooth & opens beneath nerve ring \\
Nerve ring** & $0.30-0.35(0.32)$ & $0.17-0.18(0.17)$ & $0.20-0.29(0.24)$ & $0.40-0.46(0.43)$ \\
Esophagus & $1.80-1.90(1.85)$ & $0.43-0.55(0.48)$ & $0.60-0.85(0.71)$ & $0.75-1.0(0.87)$ \\
VL & $0.85-0.94(0.89)$ & $0.05-0.075(0.06)$ & $0.22-0.32(0.27)$ & $0.10-0.13(0.11)$ \\
VW & $0.30-0.34(0.31)$ & $0.03-0.065(0.042)$ & $0.1-0.14(0.12)$ & $0.10-0.13(0.11)$ \\
Vap & absent & $0.40-0.47(0.44)$ & absent & $0.70-0.9(0.78)$ \\
Ic & absent & $0.20-0.31(0.26)$ & $0.39-0.62(0.49)$ & $0.30-0.33(0.31)$ \\
Tail & $0.10-0.15(0.12)$ & $0.08-0.11(0.093)$ & $0.10-0.15(0.12)$ & $0.19-0.32(0.27)$ \\
Mucron & $0.015-0.025(0.020)$ & absent & absent & $0.0025-0.0040(0.0035)$ \\
\hline
\end{tabular}

${ }^{*}$ Inconspicuous in some specimens; ${ }^{*}$ From anterior end; V = Ventriculus; L = Length; W = Width; Vap = Ventricular appendix; Ic = Intestinal cecum. Measurements are in millimeters with means in parentheses.

pore opening beneath the boring tooth. Ventriculus small and subspherical. Ventricular appendix nearly twice as long as the intestinal cecum. Two nearly spherical rectal glands. Tail conical and mucron absent.

\section{Terranova Leiper \& Atkinson, 1914 \\ Terranova sp.}

Main features observed in the third-stage larvae: cuticle with thin transversal striation more evident at the posterior extremity of the body. Anterior extremity with one dorsal and two poorly developed ventro-lateral lips. Six cephalic papillae, one pair in the dorsal lip and one pair in each ventro-lateral lip. Boring tooth below the oral aperture, between the ventro-lateral lips. Excretory pore opening beneath the boring tooth. Ventriculus length greater than width. Ventricular appendix absent. Intestinal cecum twice the length of the ventriculus. Two nearly spherical rectal glands. Tail conical and mucron absent.

Raphidascarididae Hartwich, 1954, sensu Fagerholm, 1991 Hysterothylacium deardorffoverstreetorum Knoff, Felizardo, Ińiguez, Maldonado Jr, Torres, Pinto \& Gomes, 2012

Main features observed in the third-stage larvae: anterior extremity with one dorsal and two poorly developed ventrolateral lips. Nine cephalic papillae, two pairs in the dorsal lip together with a large papilla and one pair in each ventro-lateral lip. Boring tooth absent. Excretory pore opening below the nerve ring. Ventriculus nearly spherical. Ventricular appendix twice as long as the esophagus. Intestinal cecum present. Four subspherical rectal glands. Tail conical and mucron present.

\section{Discussion}

The morphology and morphometry of the third-stage larvae of Anisakis sp. in the present study were in accordance with the specimens reported by Timi et al. (2001) which were collected from Engraulis anchoita Hubbs \& Marini, 1935, in Argentina and
Uruguay, and from those of Felizardo et al. (2009), from Paralichthys isosceles Jordan, 1890, in Brazil. Some slight differences observed in the length and width of the worms have been attributed to intraspecific ranges and were discussed by these authors.

The Terranova sp. larvae specimens collected in the present study were in accordance with the morphology and morphometry of the specimens collected by Timi et al. (2001) and by Felizardo et al. (2009).

The morphology and morphometry of the Contracaecum sp. larvae collected in the present study were in accordance with those described by Petter and Maillard (1988) from fish caught in the Mediterranean, and by Timi et al. (2001) and Felizardo et al. (2009) in South American marine waters.

The Hysterothylacium deardorffoverstreetorum larvae found in the present study were in accordance with the species description of Knoff et al. (2012). In the latter study larvae were collected from $P$. isosceles in the same region of Brazilian coast, from which a molecular taxonomic study was conducted describing this species, which showed taxonomic similarity to specimens previously described as Hysterothylacium sp. no 2 (PETTER; MAILLARD, 1988), Hysterothylacium MD (DEARDORFF; OVERSTREET, 1981), Hysterothylacium KB (PETTER; SEY, 1997) and Hysterothylacium sp. (PEREIRA et al., 2004).

Sabas and Luque (2003) quantitatively analyzed the components and structure of parasite communities, using 74 specimens of C. guatucupa $(23-48 \mathrm{~cm} \mathrm{tl})$ from the coast of the state of Rio de Janeiro. Most of the worm species collected were nematodes, representing $42.8 \%$ of the total. Among Anisakidae and Raphidascarididae specimens Terranova sp. (14.8\%) and Hysterothylacium sp. (83.8\%) were obtained, the infection site was the mesentery in both. The present study showed new data about this host, in relation to the previous study, such that not only was there Terranova sp. (in the mesentery), but also other larvae: Anisakis sp. (mesentery), Contracaecum sp. (mesentery and abdominal cavity) and $H$. deardorffoverstreetorum (mesentery, liver serosa and abdominal cavity), with prevalences of $13.3 \%, 10 \%$, $6.6 \%$ and $83.3 \%$, respectively. 
Timi et al. (2005) studied C. guatucupa from the southern Atlantic coast using parasites as biological tags, and reported that the abdominal cavity contained larvae of Hysterothylacium sp., Terranova sp. and Contracaecum sp., in fish from Uruguay and Argentina, and Hysterothylacium sp. and Terranova sp., in fish from Brazil. In comparison with the results from the present study, there were similarities except that in the Brazilian fish, those authors did not observe larvae of Anisakis sp. and Contracaecum sp.

Although these nematode larvae were found in the mesentery, serosa of the liver and abdominal cavity, the risks to public health cannot be ruled out, due mainly to the immunogenic characteristics of these parasites.

Moreover, there is the possibility of migration of the larvae to the musculature of the host. This migration can occur both in live fish and in dead fish after they have been caught, especially during long storage periods on boats and in warehouses. Therefore, it has been recommended that fish should be gutted on board the boat, so as to minimize the migration of these larvae. Thus, it is extremely important that sanitary surveillance professionals and other works within the fish supply chain, from catch to consumption, should be aware of parasitic diseases of fish and forms of prophylaxis, with implementation of sanitary education programs at all levels (DIAS et al., 2010, 2011).

In 2010 one case of human anisakidosis in Brazil was reported. It was diagnosed by means of gastrointestinal endoscopy, which showed the presence of nematode larvae and the lesions thus caused. The nematode species was identified as Anisakis-like (CRUZ et al., 2010), and this case therefore suggests that further diagnosis ought to have included accurate species identification in order to avoid doubts.

Because the high number of cases of anisakidosis around the world, more research is needed, in addition to constant sanitary education among consumers, aimed towards giving preference to the consumption of fish that was previously frozen or cooked properly.

\section{References}

Bernardes RA, Figueiredo JL, Rodrigues AR, Fischer LG, Vooren CM, Haimovici M, et al. Peixes da zona econômica exclusiva da região Sudeste-Sul do Brasil: Levantamento com armadilhas, pargueiras e rede de arrasto de fundo. São Paulo: Editora da Universidade de São Paulo; 2005.

Bush AO, Lafferty KD, Lotz JM, Shostak AW. Parasitology meets ecology on its own terms: Margolis et al. Revisited. J Parasitol 1997; 83(4): 575-583. PMid:9267395. http://dx.doi.org/10.2307/3284227

Cruz AR, Souto PCS, Ferrari CKB, Allegretti SM, Arrais-Silva WW. Endoscopic imaging of the first clinical case of Anisakidosis in Brazil. Sci Parasitol 2010; 11(2): 97-100.

Deardorff TL, Overstreet RM. Larval Hysterothylacium (=Thynnascaris) (Nematoda:Anisakidae) from fishes and invertebrates in the Gulf of Mexico. Proc Helminthol Soc Wash 1981; 48: 113-126.

Dias FJE, São Clemente SC, Knoff M. Nematóides anisaquídeos e cestóides Trypanorhyncha de importância em saúde pública em Aluterus monoceros (Linnaeus, 1758) no estado do Rio de Janeiro, Brasil. Rev Bras Parasitol Vet 2010; 19(2): 94-97. http://dx.doi.org/10.4322/ rbpv.01902005

Dias FJE, São Clemente SC, Pinto RM, Knoff M. Anisakidae nematodes and Trypanorhyncha cestodes of hygienic importance infecting the King Mackerel Scomberomorus cavalla (Osteichthyes: Scombridae) in Brazil. Vet Parasitol 2011; 175(3-4): 351-355. PMid:21115292. http://dx.doi. org/10.1016/j.vetpar.2010.10.014

Eiras JC, Takemoto RM, Pavanelli JC. Métodos de estudo e técnicas laboratoriais em parasitologia de peixes. 2nd ed. ampl. rev. Maringá: Editora da Universidade Estadual de Maringá; 2006.

Fagerholm HP. Systematic implications of male caudal morphology in ascaridoid nematode parasites. Syst Parasitol 1991; 19(3): 215-229. http:// dx.doi.org/10.1007/BF00011888

Felizardo NN, Knoff M, Pinto RM, Gomes DC. Larval anisakid nematodes of the flounder Paralichthys isosceles Jordan, 1890 (Piscei:Teleostei) from Brazil. Neotrop Helminthol 2009; 3(2): 57-64.

Fischer LG, Pereira LED, Vieira JP. Peixes estuarinos e costeiros. 2nd ed. Rio Grande: Gráfica Pallotti; 2011.

Knoff M, Felizardo NN, Ińiguez AM, Maldonado A Jr, Torres EJL, Pinto $\mathrm{RM}$, et al. Genetic and morphological characterisation of a new species of the genus Hysterothylacium (Nematoda) from Paralichthys isosceles Jordan, 1890 (Pisces: Teleostei) of the neotropical region, state of Rio de Janeiro, Brazil. Mem Inst Oswaldo Cruz 2012; 107 (2): 186-193. PMid:22415256.

Menezes NA, Figueiredo JL. Manual de peixes marinhos do sudeste do Brasil. IV. Teleostei (3). São Paulo: Universidade de São Paulo; 1980.

Pereira J Jr, Almeida FM, Morais NCM, Vianna RT. Hysterothylacium sp. larvae (Nematoda:Anisakidae) in Micropogonias furnieri (Sciaenidae) from Rio Grande do Sul coast, Brazil. Atlântica 2004; 26 (1): 55-60.

Petter JA, Maillard C. Larves d'ascarides parasites de poissons en Méditerranée Occidentale. Bull Mus Nat Hist Nat 1988; 10: 347-369.

Petter JA, Sey O. Nematode parasites of marine fishes from Kuwait, with a description of Cucullanus trachinoti n.sp. from Trachinotus blochi. Zoosystema 1997; 19(1):35-59.

Sabas CSS, Luque JL. Metazoan parasites of weakfish, Cynoscion guatucupa and Macrodon ancylodon (Osteichthyes: Sciaenidae), from the coastal zone of the state of Rio de Janeiro, Brazil. Rev Bras Parasitol Vet 2003; 12(4):171-178.

Timi JT, Sardella NH, Navone GT. Parasitic nematodes of Engraulis anchoita Hubbs et Marini, 1935 (Pisces, engraulidae) off the Argentine and Uruguayan coasts, South West Atlantic. Acta Parasitol 2001; 46(3):186-193.

Timi JT, Luque JL, Sardella NH. Parasites of Cynoscion guatucupa along South American Atlantic coasts: evidence for stock discrimination. J Fish Biol 2005; 67(9):1603-1618. http://dx.doi.org/10.1111/j.10958649.2005.00867.x

Ubeira FM, Valinñas B, Lorenzo S, Iglesias R, Figueiras A, GarcíaVillaescusa R. Anisaquiosis y alergia: un estúdio seroepidemiológico en la Comunidad Autónoma Gallega. Xunta de Galícia: Consellería de sanidade e servicios sociais; 2000. Documentos técnicos de salud pública, n. 24. 